\title{
Analysis of Research \& Development Expenditures with Incomes and Expenses in Information Technology Sector of Borsa Istanbul
}

\section{Turker SUSMUS}

Ph. D., Professor, Ege University, Department of Business Administration

\section{Abstract}

Information Technology (IT) sector consist of many areas from computers, mobile phones, tablets to wearable technologies. Nowadays, computers and phones, and all advanced products have greatly facilitated human lifes. And they have provided everyone to access information from anywhere. Especially the development of the telephones in the last few years has brought a different dimension to the information technologies. Therefore, the IT sector is rapidly growing and developing over the years. As a result, IT sector has a very important place in human life day by day.

Corresponding Author: Turker SUSMUS

turkersusmus@gmail.com

Received: 17 November 2019

Accepted: 6 January 2019

Published: 12 January 2020

Publishing services provided by Knowledge E

(c) Turker SUSMUS. This article is distributed under the terms of the Creative Commons.

Attribution License, which permits unrestricted use and redistribution provided that the original author and source are credited.

Selection and Peer-review under the responsibility of the EBEEC Conference Committee.

\section{G OPEN ACCESS}

In this study, it will be discussed IT sector operating in Borsa Istanbul. They are traded 15 IT companies in Borsa Istanbul. It is examined structure of incomes and expenditures of IT firms in income statement. In addition, research \& development (R\&D) expenditures are analysed and they compared with other account items of income statements. The purpose of this study in Turkey is to provide information about the IT sector and financial structure. In addition, R \& D expenditures of IT companies operating in Borsa Istanbul is revealed by analyzing the income statement data.

Keywords: Research \& Development Expenditures, IT sector in Turkey, Financial Statement

Jel Classification Codes: M10-General, M15-IT Management, M19-Business Administration: Other, M41-Accounting

\section{Introduction}

In paralel to globalization, market place has turned into the rally runway and the competition has been getting harder than ever. Almost all countries are looking for a way out. This bottleneck leads especially the developing countries to economic trouble and it forces them to be one step further in global competition. The best instrument for this purpose is to focus on innovation and research \& development activities. [1]

Although it is very important to make $R$ \& $D$ investments in the production sector, it is inevitable to invest in and support information technologies in contemporary 
development. It is possible that increasing the productivity, minimization of costs and identifying and analyzing customer requirements develops information technologies sector. Countries that obtain the information in a timely and fast manner will make technological progress and make productive productions and thus reach the sustainability of economic development.

Turkey has given more importance to information and communication technology sector in recent years and began to support. The main indicator of these works is the New Incentive and R \& D Law issued for investors in 2008. On the other hand, 76.3\% of the households in Turkey have internet access. The proportion of Internet users in Turkey is around $61.2 \%$. It is estimated that this ratio will exceed 65\% in 2018.2023 is the 100th anniversary of the Republic of Turkey. Turkey's targets for 2023 include the following information and communication technology sector [2]

- Increasing the number of broadband subscribers to 30 million

- Internet connection to 14 million households at 1,000 Mbps

- Increasing the sector's share in GDP to 8\%

- Become one of the top 10 countries in e-transformation

- Gaining computer skills to $80 \%$ of the population

- Increasing that the number of companies operating to 5500 and the number of employees to 65,000 and exports to US $\$ 10$ billion in Technology Development Zones

- Increasing the size of the information and communication technologies sector by $15 \%$ annually to US $\$ 160$ billion

- Increase in the share of R \& D expenditures in GDP from $1 \%$ to $3 \%$

\section{Assumptions and Methodology}

In this study, a literature review on the IT sector has been made and national and international R \& D statistics about GDP have been used. The 6-year income statements of 14 companies in the IT sector, which are listed on Borsa Istanbul, were examined one by one. Sales of these companies, R\&D expenses, marketing and sales expenses, general management expenses and interest expenses were analyzed. 


\section{Relationship with Gdp of R\&D Expenditures in the World and In Turkey}

Globalization together with technology, internet, mobile systems, and developments in social media has not only affected the production process of the companies, but also affected their marketing and consumer habits. Businesses are required to have strong financial resources to adapt to this rapid change and development. For this reason, it is important to increase the share of R\&D expenses in GDP. For this, $R$ \& $D$ incentives for sectors should be increased [3]

Private sector innovation and research and development (R\&D) activities substantially contribute to sustainable growth. Even a short-term decline or stagnation of these activities can have detrimental consequences in the long run. Policymakers are well aware of the importance of private sector $R \& D$ and also of the fact that private $R \& D$ spending is lower than socially desirable, even in boom periods. For that reason, public support for R\&D activities is particularly important in times of an economic crisis. [4]

The R\&D expenditures may be considered as an investment in new technologies, and knowledge base. And after it can be transformed into more efficient production methods for available resources [5]

Table 1 shows the R\&D expenditures in GDP in some OECD countries for 2012-2017 [6]. Accordingly, Spain and the Netherlands and Turkey carries out R\&D spending about the same amount. Turkey's R\&D spending is more than the Balkan countries such as Greece and Romania. According to the table, the first 4 countries that make the most R\&D expenditures in OECD countries are USA, China, Japan and Germany respectively. Russia's R\&D expenditures are more than 2 times from Turkey.

Table 2 presents the share of R \& D expenditures in total GDP. In Turkey, while this rate was at $0.8 \%$ in 2012 , it was was $1 \%$ in 2017 . Although, it is $1.1 \%$ in Greece and $0.5 \%$ in Romania In 2017. As for the developed countries, in 2017, the share of R \& D expenditures in the GDP was as follows:

- US $2.8 \%$

- China $2.1 \%$

- Japan 3.2\%

- Germany 3\%

According to these results, Turkey should increase the share of GDP in R \& D spending from $1 \%$ to $2 \%$ at least 
TABLE 1: Gross domestic spending on R\&D, Total, Million US dollars, 2012--2017.

\begin{tabular}{|c|c|c|c|c|c|c|}
\hline Location & 2012 & 2013 & 2014 & 2015 & 2016 & 2017 \\
\hline Austria & 10,611 & 10,760 & 11,305 & 11,307 & 11,823 & 12,249 \\
\hline China & 281,116 & 316,340 & 344,692 & 374,910 & 410,188 & 442,721 \\
\hline France & 53,297 & 53,844 & 55,304 & 55,701 & 55,881 & 55,582 \\
\hline Germany & 95,746 & 94,635 & 98,268 & 101,548 & 104,009 & 110,085 \\
\hline Greece & 1,845 & 2,070 & 2,142 & 2,460 & 2,539 & 2,925 \\
\hline Italy & 25,777 & 26,066 & 26,800 & 27,010 & 27,934 & 28,014 \\
\hline Japan & 145,774 & 153,595 & 158,136 & 154,494 & 149,438 & 155,104 \\
\hline Netherlands & 14,413 & 14,496 & 15,052 & 15,418 & 15,851 & 16,259 \\
\hline Norway & 4,970 & 5,114 & 5,286 & 5,789 & 5,955 & 6,450 \\
\hline Poland & 7,526 & 7,542 & 8,412 & 9,325 & 9,235 & 10,388 \\
\hline Portugal & 3,748 & 3,568 & 3,500 & 3,434 & 3,607 & 3,812 \\
\hline Romania & 1,731 & 1,436 & 1,464 & 1,941 & 2,002 & 2,247 \\
\hline Russia & 34,984 & 35,557 & 37,387 & 37,308 & 37,155 & 38,135 \\
\hline Spain & 18,403 & 17,818 & 17,591 & 17,980 & 18,047 & 18,892 \\
\hline Turkey & 12,212 & 13,027 & 14,413 & 15,658 & 17,314 & 18,925 \\
\hline United Kingdom & 37,149 & 38,993 & 40,626 & 41,807 & 42,910 & 43,217 \\
\hline United States & 417,455 & 429,592 & 441,667 & 454,096 & 468,378 & 483,676 \\
\hline
\end{tabular}

Source: OECD, https://data.oecd.org/rd/gross-domestic-spending-on-r-d.htm (Access date: March 2019)

TABLE 2: Gross domestic spending on R\&D, Total, \% of GDP.

\begin{tabular}{|l|c|c|c|c|c|c|}
\hline Location & $\mathbf{2 0 1 2}$ & $\mathbf{2 0 1 3}$ & $\mathbf{2 0 1 4}$ & $\mathbf{2 0 1 5}$ & $\mathbf{2 0 1 6}$ & $\mathbf{2 0 1 7}$ \\
\hline Austria & 2.9 & 3.0 & 3.1 & 3.1 & 3.1 & 3.2 \\
\hline China & 1.9 & 2.0 & 2.0 & 2.1 & 2.1 & 2.1 \\
\hline France & 2.2 & 2.2 & 2.3 & 2.3 & 2.2 & 2.2 \\
\hline Germany & 2.9 & 2.8 & 2.9 & 2.9 & 2.9 & 3.0 \\
\hline Greece & 0.7 & 0.8 & 0.8 & 1.0 & 1.0 & 1.1 \\
\hline Italy & 1.3 & 1.3 & 1.3 & 1.3 & 1.4 & 1.4 \\
\hline Japan & 3.2 & 3.3 & 3.4 & 3.3 & 3.1 & 3.2 \\
\hline Netherlands & 1.9 & 1.9 & 2.0 & 2.0 & 2.0 & 2.0 \\
\hline Norway & 1.6 & 1.7 & 1.7 & 1.9 & 2.0 & 2.1 \\
\hline Poland & 0.9 & 0.9 & 0.9 & 1.0 & 1.0 & 1.0 \\
\hline Portugal & 1.4 & 1.3 & 1.3 & 1.2 & 1.3 & 1.3 \\
\hline Romania & 0.5 & 0.4 & 0.4 & 0.5 & 0.5 & 0.5 \\
\hline Russia & 1.0 & 1.0 & 1.1 & 1.1 & 1.1 & 1.1 \\
\hline Spain & 1.3 & 1.3 & 1.2 & 1.2 & 1.2 & 1.2 \\
\hline Turkey & 0.8 & 0.8 & 0.9 & 0.9 & 0.9 & 1.0 \\
\hline United Kingdom & 1.6 & 1.6 & 1.7 & 1.7 & 1.7 & 1.7 \\
\hline United States & 2.7 & 2.7 & 2.7 & 2.7 & 2.8 & 2.8 \\
\hline
\end{tabular}

Source: OECD, https://data.oecd.org/rd/gross-domestic-spending-on-r-d.htm (Access date: March 2019) 
According to Table 3, construction sector has the highest share of GDP during the period of 2010-2017. On the other hand, it was observed that the rates in the production sector were lower. It was observed GDP inreases in all sectors in 2010 and 2012. As it is known, between 2010 and 2013, the US and the EU have gone into monetary expansion. Because foreign capital inflows to Turkey these years, GDP might have increased in the sectors in 2010 and 2012. However, the increase in GDP in the Information and communication sector in 2014 was extremely low. Because, after Bernanke announced that it would begin reducing monetary expansion in May 2013, it might have begun to decrease foreign inflows to Turkey. As a result, the GDP growth in 2014 felt down considerably. While the share of the IT sector increased in 2010, 2012 and 2015, it entered a declining trend in 2016 and 2017.

TABLE 3: The Share of Turkey's GDP in the Sectors (2010-2017).

\begin{tabular}{|c|c|c|c|c|c|c|c|c|}
\hline Sectors & 2010 & 2011 & 2012 & 2013 & 2014 & 2015 & 2016 & 2017 \\
\hline $\begin{array}{l}\text { Agriculture, forestry } \\
\text { and fishing }\end{array}$ & $39.3 \%$ & $-6.0 \%$ & $6.8 \%$ & $-8.6 \%$ & $-3.9 \%$ & $15.4 \%$ & $-9.7 \%$ & $-4.9 \%$ \\
\hline Manufacturing & $25.0 \%$ & $12.4 \%$ & $9.3 \%$ & $7.7 \%$ & $1.4 \%$ & $9.6 \%$ & $0.1 \%$ & $2.2 \%$ \\
\hline $\begin{array}{l}\text { Water supply, } \\
\text { sewerage, waste } \\
\text { management and } \\
\text { remediation activities }\end{array}$ & $30.3 \%$ & $-0.7 \%$ & $18.0 \%$ & $4.7 \%$ & $-4.6 \%$ & $1.5 \%$ & $0.1 \%$ & $-2.8 \%$ \\
\hline Construction & $36.1 \%$ & $21.2 \%$ & $18.3 \%$ & $13.5 \%$ & $-1.4 \%$ & $10.8 \%$ & $5.9 \%$ & $-3.4 \%$ \\
\hline $\begin{array}{l}\text { Trade,Transport and } \\
\text { Accomodation }\end{array}$ & $22.4 \%$ & $4.5 \%$ & $16.1 \%$ & $4.3 \%$ & $0.1 \%$ & $9.6 \%$ & $-2.3 \%$ & $-0.1 \%$ \\
\hline $\begin{array}{l}\text { Information and } \\
\text { communication }\end{array}$ & $13.5 \%$ & $-2.9 \%$ & $17.7 \%$ & $4.4 \%$ & $-0.6 \%$ & $9.3 \%$ & $2.2 \%$ & $0.1 \%$ \\
\hline $\begin{array}{l}\text { Financial and } \\
\text { insurance activities }\end{array}$ & $-1.5 \%$ & $-5.2 \%$ & $23.1 \%$ & $10.4 \%$ & $-8.4 \%$ & $14.6 \%$ & $12.4 \%$ & $-6.2 \%$ \\
\hline Real estate activities & $18.5 \%$ & $-6.8 \%$ & $9.2 \%$ & $0.4 \%$ & $-4.5 \%$ & $6.2 \%$ & $0.8 \%$ & $-10.3 \%$ \\
\hline $\begin{array}{l}\text { Professional, } \\
\text { Administrative and } \\
\text { Support Service } \\
\text { Activities }\end{array}$ & $20.2 \%$ & $3.6 \%$ & $18.5 \%$ & $9.1 \%$ & $2.3 \%$ & $18.1 \%$ & $2.1 \%$ & $-0.2 \%$ \\
\hline $\begin{array}{l}\text { Public Administ., } \\
\text { Education, Human } \\
\text { Health and Social } \\
\text { Work Activities }\end{array}$ & $22.0 \%$ & $-1.7 \%$ & $16.2 \%$ & $2.6 \%$ & $-0.3 \%$ & $7.1 \%$ & $7.0 \%$ & $-9.0 \%$ \\
\hline Other service activities & $25.4 \%$ & $2.9 \%$ & $13.2 \%$ & $8.6 \%$ & $-0.4 \%$ & $4.6 \%$ & $1.3 \%$ & $-6.0 \%$ \\
\hline Taxes-Subsidies & $40.1 \%$ & $2.6 \%$ & $10.7 \%$ & $11.2 \%$ & $-8.6 \%$ & $13.3 \%$ & $0.7 \%$ & $-7.3 \%$ \\
\hline
\end{tabular}

Source: TUIK, http://www.tuik.gov.tr (Access date: March 2019)

Table 4 shows the GDP amount in terms of euro by sectors. Accordingly, the information and communication sector regularly increased every year except for the GDP of 2014. The GDP of this sector has ranged from 12.6 billion to 19 billion euro. The average annual amount of GDP is $16,441,243,000$ euro. This amount corresponds to an average 


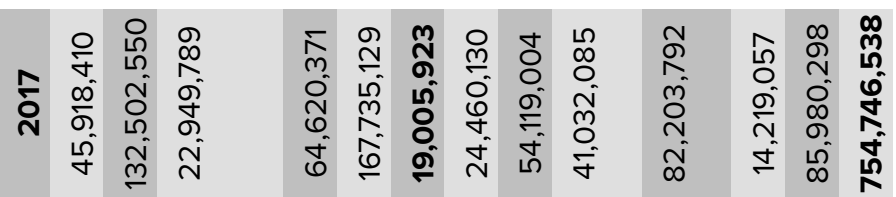

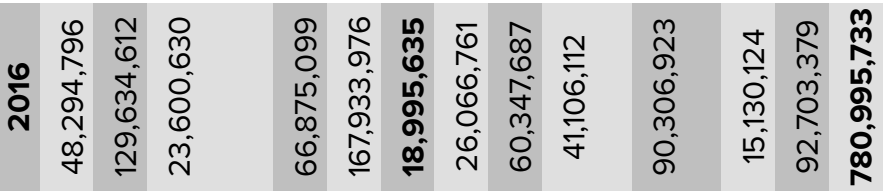

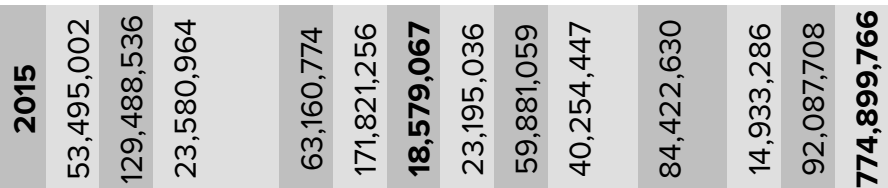

年

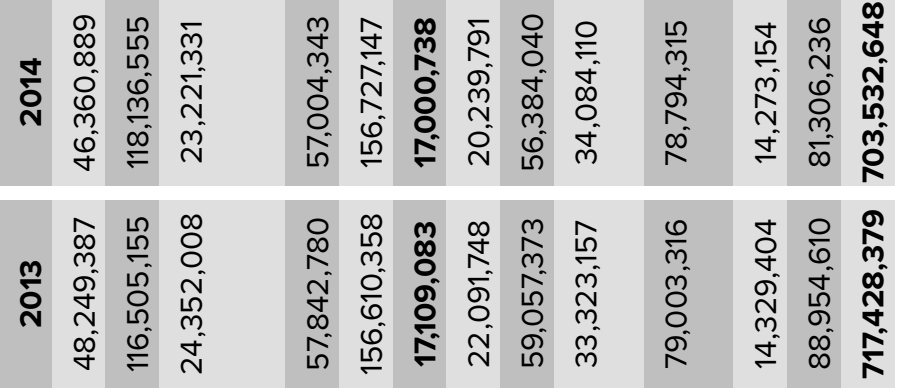

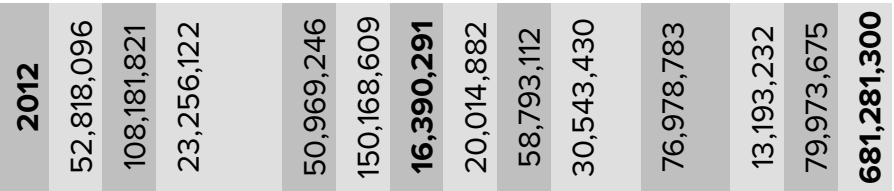

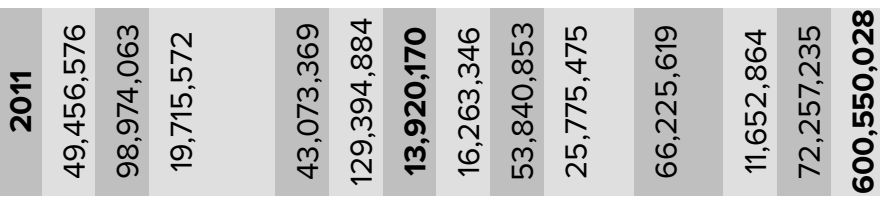

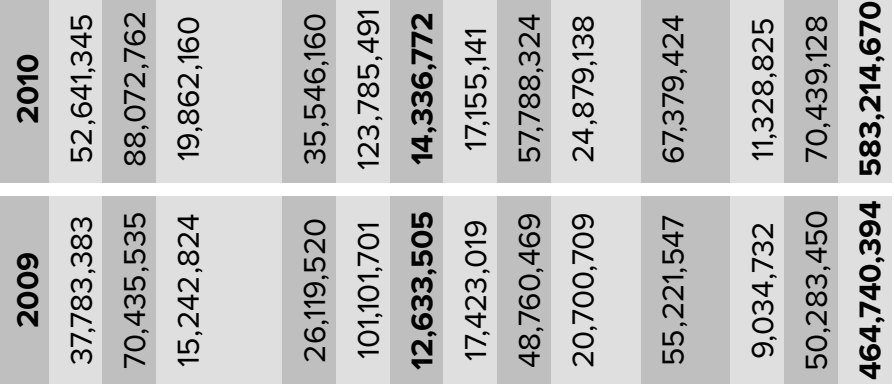

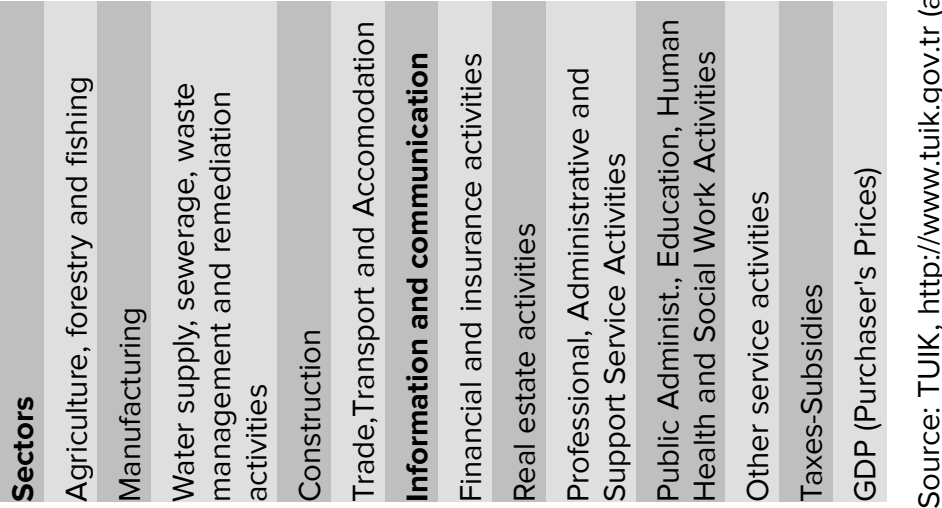


of $2.4 \%$ in all sectors. It is useful to pay attention to this point. Because exchange rates in Turkey before 2016 was low, a rate of $2.4 \%$ may have occurred.

When the Global Competitiveness Reports are examined from 2012-2018 [7], table 5 will be reached, announced by the World Economic Forum. The World Economic Forum (WEF) has published the Global Competitiveness Report, which has been ranked by its competitiveness, since 1979. Global Competitiveness Report series have been providing policy-makers and other stakeholders around the world with an annual assessment of the drivers of long-term growth. At the heart of the competitiveness agenda is the recognition that economic growth is a core driver of human development [8]

WEF uses qualitative indicators obtained from international sources and qualitative indicators obtained from the Manager Opinion Survey data. Quantitative indicators are indicators of data such as inflation rate, public debt and internet access rate of countries. Qualitative indicators are obtained as a result of surveys conducted with company managers. These indicators are information on institutional factors such as judicial independence, the existence of corruption. In calculating the index, three main factors are used, consisting of 12 components and complementary data. The first basic factor is the Basic Requirements, which consist of Institutions, Infrastructure, Macroeconomic Environment, Health and Basic Education. Secondly, Productivity Improving Factors is the combination of Higher Education and Vocational Training, Efficiency of Goods Market, Efficiency of Labor Market, Financial Market Development, Technological Preparation and Market Size. The last factor is the Innovation and Diversity Factors that cover the Development Level of the Labor Market and Innovative Data. [9]

TABLE 5: Turkey's Rank in almost 140 Countries on The Global Competitiveness.

\begin{tabular}{|l|c|}
\hline Years & $\begin{array}{c}\text { Rank in almost } \mathbf{1 4 0} \\
\text { Countries }\end{array}$ \\
\hline $2012-2013$ & 43 \\
$2013-2014$ & 44 \\
$2014-2015$ & 45 \\
$2015-2016$ & 51 \\
$2016-2017$ & 55 \\
2018 & 61 \\
\hline
\end{tabular}

Source: World Economic Forum, The Gloal Competitiveness Reports, 2012-2016

According to table 5, in 140 countries, Turkey's competitiveness ranking has been in a downtrend since 2012-2013. Although Turkey is the forty-third in 140 countries in 2012-2013, it's ranking orderly continued to fall and in 2018 it has placed to ranking sixty-first. 


\section{Empirical Relation Between R\&D and Economic Growth}

There are three important factors supporting economic growth: (1) Capital accumulation, such as all new investments in land, physical equipment, and human resources, (2) Growth in the labor force, and (3) Technological Progress. Recently, new growth theories have stressed the importance of technological change as a source of economic growth. These theories support the view that the key driver for economic growth in global economies is innovation. Also, many studies have researched the extent of the contribution that innovation continues to have upon competitiveness and the growth of firms, industries, and national economies [10] The R\&D expenditures may be considered as an investment in new technologies, and knowledge base. And after it can be transformed into more efficient production methods for available resources [5]

Growth rates of virtually all economic variables are time varying. The reasons for these fluctuations are manyfold. Companies that spend $R \& D$ and target profit maximization may be the source of long-term positive growth rates of countries [11.]There are many the following studies that trying to explain the relationship between investment in R\&D and growth [10]

- Hall (1996) showed in his article that investment in R\&D is positively correlated with firms' profitability and productivity, and produces a relatively high private rate of return.

- Scherer (1982), Griliches and Lichten erg (1984), Aghion and Howitt (1998), and Zachariadis (2003) present strong evidence that R\&D investment and growth are positively related in the US economy

- Sadraoui and Zina, (2009) examined the dynamic relationship between cooperation in R\&D and economic growth by using the Generalised Moment Method and panel data from a sample of 23 countries between 1992 and 2004. Results showed a positive and significant relation between R\&D cooperation and economic growth for all the countries sampled.

- Griffith, Redding and Van Reenen (2004) claimed that research and development (R\&D) has two faces. The first face is in stimulating innovation. Second face is in making easy the imitation of discoveries by others. They researched this two faces empirically using a panel of industries across twelve OECD countries. They found that R\&D is statistically and economically important in both technological and innovation. 
- Further, Wakelin (2001) analyzed relationships between productivity growth and R\&D expenditures in 170 firms on the UK stock market. The research findings showed that a has a positive and significant role in influencing its productivity growth.

- Samimi and Alerasoul (2009) researched the impact of R\&D on economic growth in developing countries. They used a sample of 30 developing countries for which the necessary data is available for the period 2000 to 2006 . According to their analyses, the low R\&D expenditures of developing countries have no important effect on economic growth.

- Bayarcelik and Tasel (2012) determined that there was a positive and significant relationship between R\&D investment and number of the employees in the R\&D department with GDP

Ozcan et al (2014) examine that the relationship between R\&D expenditures and economic growth is analyzed for the selected 15 OECD countries from 1990-2011 within the framework of panel data model. According to this analysis, R\&D expenditures positively affects economic growth. (12) On the other hand, in a study, which researches the relationship between R\&D expenditures and economic growth, the Johansen Cointegration Test and the Granger Causality Test are applied by using the data covering the period of 1990 to 2013 in Turkey. As a result of the tests conducted, it is concluded that there is no long-term relationship between real R\&D expenditures and economic growth series. [5]

Conversely from the related universal literature, it is concluded that there is no relationship between R\&D expenditures and economic growth as a result of the empirical tests applied. This case can be explain that Turkey is a developing country, and the investment volumes allocated to R\&D expenditures show considerable increases in recent decades. Thus, the R\&D activities need a long-term technical effort, and the benefits of those expenditures distribitued in this area can be seen in the economy in a period of next 20 or 35 years. [5]

\section{Analyzing of R\&D and the Other Expenses of Turkish Information Technology Companies in Borsa Istanbul}

In this section, $\mathrm{R}$ \& D expenses and other expenses of IT companies registered in Borsa Istanbul will be examined. As I explained in the study, there is a positive relationship with $R$ \& $D$ expenditures and growth rates of countries. However, in another study 
conducted as for Turkey, (5) R \& D expenditure has been determined that there is no positive relationship between growth rates. They argued that Turkey 's is a developing country, while the results of $R \& D$ spending will emerge after many years not in a short time.

Aytekin and Ozcalik [13] researched to determine the relationship between R\&D expenditures and the financial performance of companies. For this purpose, R\&D and performance data of 7 companies which are continuously listed in Borsa Istanbul Technology and Information Technology Indices between 2011:Q1 - 2018:Q1 have been used. According to researchers, they found a positive relationship between EBIT and $R$ \& D Expenditures and Market Value / Book Value. In addition, although they determined a positive correlation between Net Sales and R \& D Expenditures, a negative significant relationship was found between R \& D / Total Operating Expenses. [13]

Dağl $\iota$ and Ergün (2017) analyzed the R \& D expenditures of 66 manufacturing firms in Borsa istanbul between 2010-2013. Accordingly, a positive relationship was found between $R$ \& $D$ expenditures and ROA. In addition, expenditures on $R$ \& $D$ activities affect the ROA with a delay of one year. As the new $R \& D$ expenditures increase, the profitability of the companies is increasing. This increase in the profit is realized one year after the expenditure. [14]

In 2018, Aytekin and Ozcalik [13] conducted a new study on the relationship between $R$ \& D expenses and financial performance. Therefore, the relationship between $R$ \& $D$ expenses and financial performance is not researched in this study. The aim of this study is to show the revenues, the cost of sales, R \& D Expenses, Marketing and Sales Expenses, General Management Expenses, Financing Expenses and Operating Profits of IT companies in Borsa Istanbul. Thus, it will be easily determined the share of IT companies' income and expenses. In my opinion, it would be useful to determine whether IT companies made R \& D expenditures or which IT companies spent R \& D expenditures in Borsa Istanbul.

Except for the Borsa Istanbul, Turker et al [3] realized a similar research for other companies in Turkey. Susmus, Caki and Can researched statements of income of 1289 small-size manufacturing enterprises, 876 medium-sized manufacturing enterprises and 571 large-scale manufacturing companies about $R \& D$ expenses. The aim of their analysis was to determine the proportion of $R \& D$ expenses in sales and in operating expenses of the manufacturing enterprises. According to their research; [3]

- The rate of R\&D expenses to the net sales is $0.22 \%$ in small-sized Manufacturing enterprises in 2014 
- The rate of R\&D expenses to the net sales is $0.15 \%$ in medium-sized Manufacturing enterprises in 2014

- The rate of R\&D expenses to the net sales is $0.40 \%$ in large-sized Manufacturing enterprises in 2014

As can be seen from Table 6, there are 14 IT Sector companies in Borsa Istanbul. The income and expenses of these companies for the years 2013-2018 are presented in detail in Euro as yearly average in the table below. Determinations for companies are as follows:

- The average annual sales of companies range from 2,2 million euros to 915 million euros.

- Half of the 14 companies did not spend R \& D. R \& D expense in Borsa Istanbul IT sector is 1,85 million euro per company yeartly

- The average annual R \& D expenditure in the sector is 26 million euros.

- Interest expenses of all companies in the IT sector are twice as much as R \& D expenses. Accordingly, the total interest costs is 48,7 million euros.

- IT sector total annual administrative expenses is 51,1 million euro, marketing and sales expenses are 55,2 million euros.

- The average annual sales of companies ranged from 2.2 million euros to 915 million euros.

- The company that makes the highest $R$ \& $D$ expenditure in the sector is LOGO SOFTWARE and it has the highest profit in the sector.

Table 7 shows the ratio of the expenses of the companies to the sales and the ratio of the profits to the sales. According to Table 7, the following results are possible:

- R \& D expenses / sales ratio in the sector is $1 \%$. However, half of the companies in the sector do not have $R \& D$ activities. When only 7 companies, which have $R$ \& $D$ activity, are examined, $R$ \& D Expenses / Sales ratio is $8.8 \%$

- General Management Expenses / Sales ratio in the sector is 2\%

- Marketing and Sales Expenses / Sales ratio in the sector is $2.2 \%$

- Interest Expenditures / Sales ratio in the sector is 1.9\%

- The cost of sales / sales in the sector is $90.9 \%$. The IT sector is a labor-intensive sector with high labor costs. Because the software companies generally pay high wages to engineers 

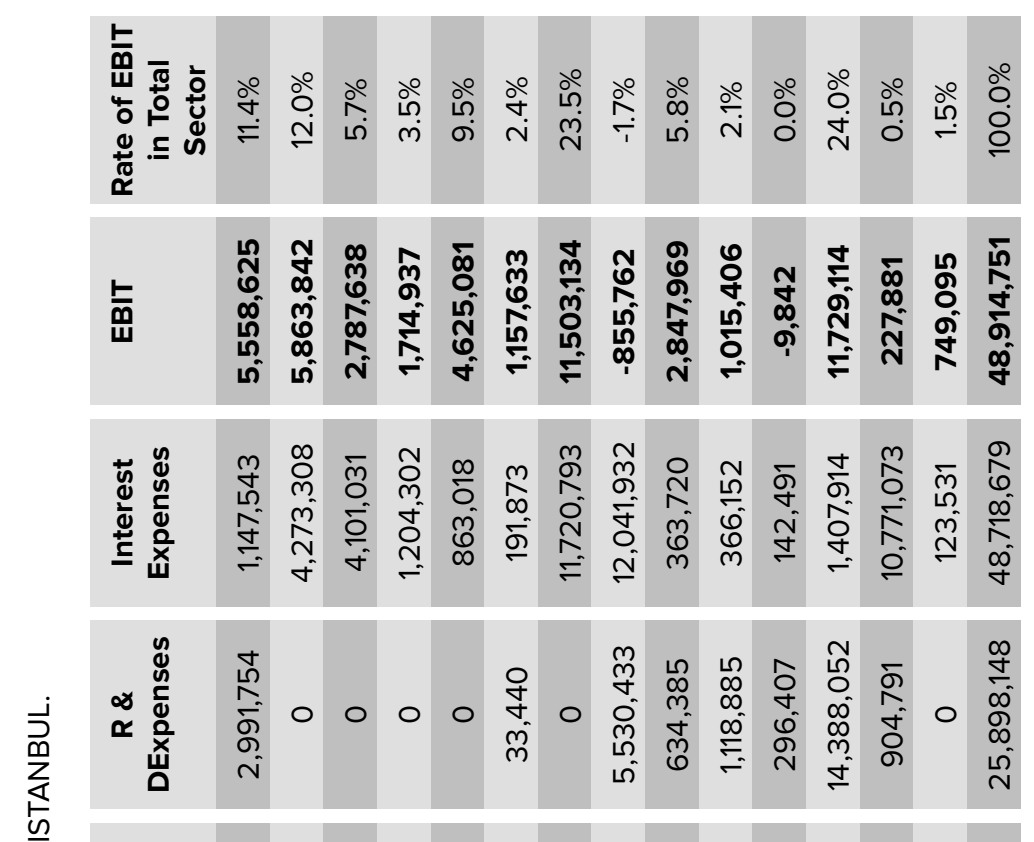

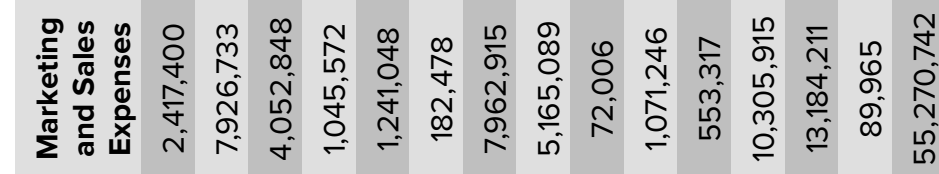

옫

.

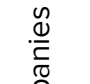

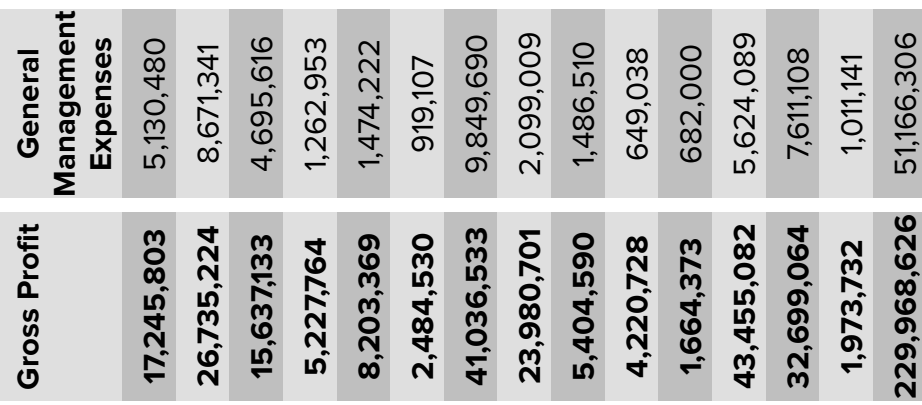

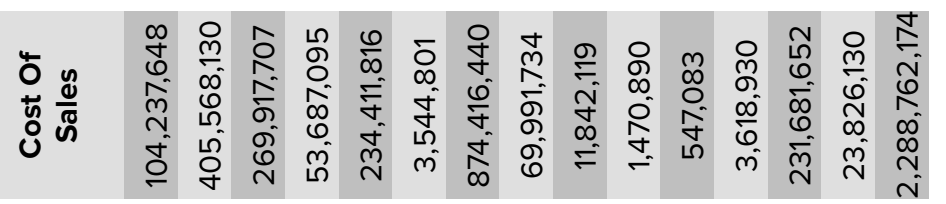

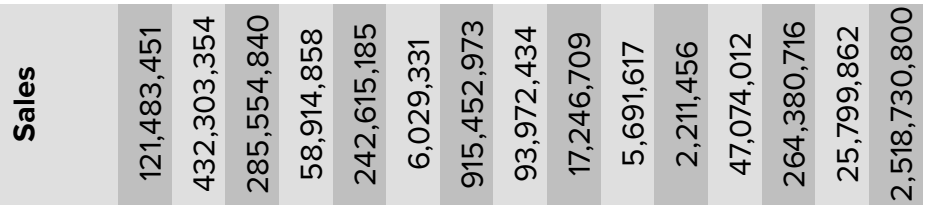

咅 : 
TABLE 7: All Expense Rate in Sales of Information \& Technology Companies in Borsa ISTANBUL.

\begin{tabular}{|c|c|c|c|c|c|c|}
\hline & $\begin{array}{l}\text { Rate of R\&D } \\
\text { Expenses }\end{array}$ & $\begin{array}{l}\text { Rate of GM } \\
\text { Expenses }\end{array}$ & $\begin{array}{l}\text { Rate of M\&S } \\
\text { Expenses }\end{array}$ & $\begin{array}{c}\text { Rate of } \\
\text { Interest } \\
\text { Expenses }\end{array}$ & $\begin{array}{c}\text { Rate of Cost } \\
\text { of Sales }\end{array}$ & Rate of EBIT \\
\hline $\begin{array}{l}\text { Alcatel Lucent } \\
\text { Teletaș }\end{array}$ & $2.5 \%$ & $4.2 \%$ & $2.0 \%$ & $0.9 \%$ & $85.8 \%$ & $4.6 \%$ \\
\hline Arena Computer & - & $2.0 \%$ & $1.8 \%$ & $1.0 \%$ & $93.8 \%$ & $1.4 \%$ \\
\hline Armada Computer & - & $1.6 \%$ & $1.4 \%$ & $1.4 \%$ & $94.5 \%$ & $1.0 \%$ \\
\hline Despec Computer & - & $2.1 \%$ & $1.8 \%$ & $2.0 \%$ & $91.1 \%$ & $2.9 \%$ \\
\hline Datagate Computer & - & $0.6 \%$ & $0.5 \%$ & $0.4 \%$ & $96.6 \%$ & $1.9 \%$ \\
\hline $\begin{array}{l}\text { Fonet Information } \\
\text { Technology }\end{array}$ & $0.6 \%$ & $15.2 \%$ & $3.0 \%$ & $3.2 \%$ & $58.8 \%$ & $19.2 \%$ \\
\hline Index Computer & - & $1.1 \%$ & $0.9 \%$ & $1.3 \%$ & $95.5 \%$ & $1.3 \%$ \\
\hline Karel Electronic & $5.9 \%$ & $2.2 \%$ & $5.5 \%$ & $12.8 \%$ & $74.5 \%$ & $-0.9 \%$ \\
\hline Kafein Software & $3.7 \%$ & $8.6 \%$ & $0.4 \%$ & $2.1 \%$ & $68.7 \%$ & $16.5 \%$ \\
\hline $\begin{array}{l}\text { Kron } \\
\text { Telecommunication }\end{array}$ & $19.7 \%$ & $11.4 \%$ & $18.8 \%$ & $6.4 \%$ & $25.8 \%$ & $17.8 \%$ \\
\hline Link Computer & $13.4 \%$ & $30.8 \%$ & $25.0 \%$ & $6.4 \%$ & $24.7 \%$ & $-0.4 \%$ \\
\hline Logo Software & $30.6 \%$ & $11.9 \%$ & $21.9 \%$ & $3.0 \%$ & $7.7 \%$ & $24.9 \%$ \\
\hline Netas Telekom & $0.3 \%$ & $2.9 \%$ & $5.0 \%$ & $4.1 \%$ & $87.6 \%$ & $0.1 \%$ \\
\hline Plasticcard & - & $3.9 \%$ & $0.3 \%$ & $0.5 \%$ & $92.3 \%$ & $2.9 \%$ \\
\hline Total & $1.0 \%$ & $2.0 \%$ & $2.2 \%$ & $1.9 \%$ & $90.9 \%$ & $1.9 \%$ \\
\hline
\end{tabular}

- The EBIT / Sales ratio of the IT sector is $1.9 \%$

- The companies with the highest $R$ \& $D$ expenses in the sector are KRON TELECOMMUNICATION and LOGO SOFTWARE. These two companies are also the first two companies with the highest profitability in the sector. Accordingly, the two companies that have a high $\mathrm{R} \& \mathrm{D}$ expenditure also have the highest profitability.

- There are 2 companies in the industry that have loss: LINK COMPUTER AND KAREL ELECTRONIC. In addition, these two companies also pay the highest interest expenses.

When Table 8 is analyzed, the sales in the sector was realized the same amount between the years 2015-2018. In 2018, sales decreased by $29 \%$ compared to 2017. This result may have arisen in 2018 because exchange rates (Euro/TL) rose more than in previous years. Eyuboglu and Eyuboglu (2018) found their research that the increase in the USD / TL exchange rate had a statistically significant and negative effect on the IT sector. [16]

When Table 9 is examined, it is observed that the companies that have more hardware sales do not spend $R \& D$, but the companies that work on software make $R$ 
TABLE 8: Sales of Information \& Technology Companies in Borsa ISTANBUL (Euro).

\begin{tabular}{|c|c|c|c|c|c|c|}
\hline & 2013 & 2014 & 2015 & 2016 & 2017 & 2018 \\
\hline $\begin{array}{l}\text { Alcatel } \\
\text { Lucent } \\
\text { Teletaş }\end{array}$ & $141,100,800$ & $128,625,047$ & $109,458,448$ & $131,904,573$ & $120,243,874$ & $97,567,963$ \\
\hline $\begin{array}{l}\text { Arena } \\
\text { Computer }\end{array}$ & $399,352,634$ & $424,375,191$ & $468,762,502$ & $467,859,153$ & $443,084,848$ & $390,385,798$ \\
\hline $\begin{array}{l}\text { Armada } \\
\text { Computer }\end{array}$ & $213,521,374$ & $252,564,263$ & $307,246,216$ & $312,722,754$ & $324,820,955$ & $302,453,476$ \\
\hline $\begin{array}{l}\text { Despec } \\
\text { Computer }\end{array}$ & $56,057,334$ & $56,690,815$ & $58,454,963$ & $57,771,416$ & $63,323,879$ & $61,190,742$ \\
\hline $\begin{array}{l}\text { Datagate } \\
\text { Computer }\end{array}$ & $62,415,441$ & $156,408,962$ & $356,984,923$ & $363,598,955$ & $384,588,828$ & $131,694,000$ \\
\hline $\begin{array}{l}\text { Fonet } \\
\text { Informa- } \\
\text { tion } \\
\text { Technol- } \\
\text { ogy }\end{array}$ & & & & & $5,752,062$ & $6,306,601$ \\
\hline $\begin{array}{l}\text { Index } \\
\text { Computer }\end{array}$ & $640,346,629$ & $759,125,715$ & $1,121,501,286$ & 1,135,809,177 & $1,146,653,240$ & $689,281,791$ \\
\hline $\begin{array}{l}\text { Karel } \\
\text { Electronic }\end{array}$ & $72,345,217$ & $75,045,775$ & $84,793,995$ & $96,365,457$ & $106,482,313$ & $128,801,849$ \\
\hline $\begin{array}{l}\text { Kafein } \\
\text { Software }\end{array}$ & & & & & & $17,246,709$ \\
\hline $\begin{array}{l}\text { Kron Tele- } \\
\text { communi- } \\
\text { cation }\end{array}$ & $3,921,585$ & $4,643,063$ & $4,828,345$ & $8,154,525$ & $6,665,461$ & $5,936,724$ \\
\hline $\begin{array}{l}\text { Link } \\
\text { Computer }\end{array}$ & $2,163,529$ & $2,213,482$ & $2,524,843$ & $2,139,360$ & $2,191,904$ & $2,035,620$ \\
\hline $\begin{array}{l}\text { Logo } \\
\text { Software }\end{array}$ & $28,040,149$ & $35,798,567$ & $42,669,777$ & $56,998,235$ & $62,237,345$ & $56,700,000$ \\
\hline $\begin{array}{l}\text { Netas } \\
\text { Telekom }\end{array}$ & $250,341,218$ & $254,975,610$ & $334,325,082$ & $290,372,283$ & $272,659,301$ & $183,610,803$ \\
\hline Plasticcard & $25,199,664$ & $20,079,167$ & $24,387,156$ & $24,846,816$ & $30,485,060$ & $29,801,311$ \\
\hline $\begin{array}{l}\text { Total } \\
\text { Sales }\end{array}$ & $1,894,805,575$ & $2,170,545,657$ & $2,915,937,535$ & $2,948,542,703$ & 2,969,189,071 & $2,103,013,385$ \\
\hline
\end{tabular}

Source: Constituted from me by using http://finans.mynet.com/ and data have been converted into Euro

\& $D$ expenditures. While the $R \& D$ expenditures of the IT sector increased regularly until 2017, R \& D expenditures decreased by $28.4 \%$ in 2018. (Fonet Information Technology registered to Borsa Istanbul in 2017 and Kafein Software registered to it in 2018)

Table 10 was formed from the data in Table 8 and 9. KAFEIN has 1 year data because it joined Borsa Istanbul in 2018. When Table 10 is analyzed, KRON, LOGO and LINK have the lowest annual sales share in IT sector, but these 3 companies have the highest $R$ \& $D$ expenditure in IT sector. The total sales of these three companies in the IT sector was $3.76 \%+0.23 \%+1.88 \%=5.87 \%$. The ratio of these three companies in total 
TABLE 9: R\&D Expenses of Information \& Technology Companies in Borsa ISTANBUL (Euro).

\begin{tabular}{|c|c|c|c|c|c|c|}
\hline & 2013 & 2014 & 2015 & 2016 & 2017 & 2018 \\
\hline $\begin{array}{l}\text { Alcatel } \\
\text { Lucent } \\
\text { Teletaș }\end{array}$ & $2,548,777$ & $2,688,662$ & $3,693,369$ & $3,280,423$ & $3,443,602$ & $2,295,693$ \\
\hline $\begin{array}{l}\text { Fonet } \\
\text { Information } \\
\text { Technology }\end{array}$ & & & & & 64,060 & 2,820 \\
\hline $\begin{array}{l}\text { Karel } \\
\text { Electronic }\end{array}$ & $4,125,583$ & $5,784,757$ & $5,947,160$ & $5,714,454$ & $6,276,426$ & $5,334,217$ \\
\hline $\begin{array}{l}\text { Kafein } \\
\text { Software }\end{array}$ & & & & & & 634,385 \\
\hline $\begin{array}{l}\text { Kron Tele- } \\
\text { communicat- } \\
\text { ion }\end{array}$ & 494,715 & 822,139 & $1,118,445$ & 1,395,970 & $1,645,037$ & $1,237,005$ \\
\hline $\begin{array}{l}\text { Link } \\
\text { Computer }\end{array}$ & 317,122 & 296,149 & 296,463 & 297,113 & 297,605 & 273,992 \\
\hline $\begin{array}{l}\text { Logo } \\
\text { Software }\end{array}$ & $6,780,331$ & $10,072,522$ & $12,209,168$ & $17,774,891$ & $24,780,688$ & $14,710,709$ \\
\hline $\begin{array}{l}\text { Netas } \\
\text { Telekom }\end{array}$ & 285,603 & 427,566 & $1,314,868$ & & $1,033,158$ & $2,367,552$ \\
\hline $\begin{array}{l}\text { Total R\&D } \\
\text { Expenses }\end{array}$ & $14,552,132$ & $20,091,796$ & $24,579,473$ & $28,462,851$ & $37,540,576$ & $26,856,373$ \\
\hline
\end{tabular}

Source: Constituted from me by using http://finans.mynet.com/ and data have been converted into Euro

TABLE 10: Sales and R \& D Expenditures in IT Sector Between 2013 and 2018.

Companies
Alcatel Lucent Teletaş
Arena Computer
Armada Computer
Despec Computer
Datagate ComputerTechnology
Fonet Information Technology
Index Computer
Karel Electronic
Kafein Software
Kron Telecommunication
Link Computer
Logo Software
Netas Telekom
Plasticcard
Total

\begin{tabular}{|c|}
\hline $\begin{array}{c}\text { Rate of Sales in Sector } \\
\text { Total Sales }\end{array}$ \\
\hline $4.86 \%$ \\
\hline $17.29 \%$ \\
\hline $11.42 \%$ \\
\hline $2.36 \%$ \\
\hline $9.70 \%$ \\
\hline $0.08 \%$ \\
\hline $36.61 \%$ \\
\hline $3.76 \%$ \\
\hline $0.11 \%$ \\
\hline $0.23 \%$ \\
\hline $0.09 \%$ \\
\hline $1.88 \%$ \\
\hline $10.57 \%$ \\
\hline $1.03 \%$ \\
\hline $100 \%$ \\
\hline
\end{tabular}

Rate of R\&D Expensesin Sector Total R\&D Expenses

\begin{tabular}{|c|c|}
\hline $11.80 \%$ \\
\hline $0.04 \%$ \\
\hline- \\
\hline- \\
\hline $\mathbf{2 1 . 8 2} \%$ \\
\hline $0.42 \%$ \\
\hline $\mathbf{4 . 4 1} \%$ \\
\hline $1.17 \%$ \\
\hline $\mathbf{5 6 . 7 6} \%$ \\
\hline $3.57 \%$ \\
\hline-
\end{tabular}

$R$ \& $D$ expenses within the IT sector is $21.82 \%+4 i 41 \%+56 i 76 \%=83 \%$. Here is a very 
interesting result. Although these 3 companies have the lowest sales share, they cover $83 \%$ of all $R$ \& $D$ expenses in the sector. When the activities of these three companies are analyzed, it is understood that they operate completely on software technologies.

\section{Conclusion}

It is mentioned firstly relationship with GDP of R\&D expenditures in the world and in Turkey. Then, it is explained the share of Turkey's GDP according to Sectors. It is mentioned firstly relationship with GDP of R\&D expenditures in the world and in Turkey. Then, it is explained the share of Turkey's GDP according to Sectors. In many studies, a positive relationship was found between the growth rates of countries and $R \& D$ expenditures. In this study, income statements of 14 IT Sector companies operating in Borsa Istanbul were analyzed. According to the results, the $R \& D$ expenses / sales ratio of the sector is $1 \%$. Half of the companies in the sector are spending R \& D. Companies with more hardware sales do not spend $R$ \& D. However, companies working on software are spending on R \& D. R \& D Expenditures / Sales of 7 companies engaged in $R$ \& $D$ are $8,8 \%$. General Management Expenses / Sales ratio of the sector is $2 \%$, Marketing and Sales Expenses / Sales ratio is 2.2\%. R \& D Expenses / Sales ratio in the sector should be increased to at least 3\%. On the other hand, the sector's EBIT / Sales ratio is $1.9 \%$, which is quite low. It was observed that there was a lack of financing in the sector. Interest Expenditure / Sales ratio is 1.9\% and this ratio is about 2 times the $\mathrm{R} \& \mathrm{D}$ expenses / Sales ratio. IT sector companies need to reduce interest expenses in order to have a high level of competitiveness. The cost of sales / sales

is $90.9 \%$ because software engineers work at high wage rates. IT sector companies should increase their exports. While the sales in the sector were the same between 2015-2018, it decreased by $29 \%$ in 2018 . Similarly, the R \& D expenditures of the sector increased steadily until 2017 , while they decreased by $28.4 \%$ in 2018 . Due to the fact that Turkey in the Euro / TL rate was increase in high amounts, these results may have arisen in 2018. This is very interesting results that although these 3 companies have the lowest sales $(\% 5,87)$ share, they cover $83 \%$ of all $R \& D$ expenses in the sector. It determined that these three companies work about software technologies. In this paper, the last 6 years of IT sector firms operating in Borsa Istanbul are examined. In recent years, IT sector has started to give more importance to $R \& D$ projects. Therefore, this paper is thought to be a guide for other future studies on $R \& D$ expenditures for IT sector. 


\section{References}

[1] Türkiye'de Ar-Ge Düzenlemeleri ve Uygulamaları. Ozeroğlu, Ali ihsan. 36, 2011, Cilt 9, s. 105-114.

[2] http://www.invest.gov.tr

[3] Susmus, Turker, Caki S. Sertac and Can, Dincer (2016), "Financial Incentives for Research and Development Practices in Turkey", Proceedings of the 8th International Conference 'The Economies of Balkan and Eastern Europe Countries in the Changing World' EBEEC 2016, Split, Croatia May 6-8, pp. 158-173

[4] Hud, Martin and Hussinger, Katrin (2015), "The impact of R\&D subsidies during the crisis", Research Policy, 44, 1844--1855

[5] Tuna, Kadir; Kayacan Emir and Bektas Hakan (2015), "The Relationship Between Research \& Development Expenditures and Economic Growth: The Case of Turkey", Procedia - Social and Behavioral Sciences 195, 501 -- 507

[6] OECD, https://data.oecd.org/rd/gross-domestic-spending-on-r-d.htm (Access date: March 2019)

[7] World Economic Forum. The Global Competitiveness Report. 2012-2016.

[8] World Economic Forum, The Global Competitiveness Report 2018

[9] Ovali, Serap (2014), "Küresel Rekabet Gücü Açısından Türkiye'nin Konumu Üzerine Bir Değerlendirme", International Journal of Economic and Administrative Studies, Year:7 Number 13, Summer, pp. 17-36

[10] Bayarcelik, Ebru Beyza and Tasel Fulya (2012), "Research and Development: Source of Economic Growth", Procedia - Social and Behavioral Sciences 58, 744 -- 753

[11] Walde, Klaus and Woitek, Ulrich (2004), "R\&D expenditure in G7 countries and the implications for endogenous fluctuations and growth", Economics Letters 82, 91--97

[12] Akçali, Burçay Yasar and Sismanoğlu, Elcin (2015), Innovation and the Effect Research and Development (R\&D) Expenditure on Growth in Some Developing and Developed Countires, Procedia - Social and Behavioral Sciences 195, 768 -- 775

[13] Aytekin, Sinan and Ozcalik, Sevinc Guler (2018), "Relationship Between R\&D Expenditure and Financial Performance on Technology and Information Technology Indices Firms in Borsa Istanbul", Anemon, 2018 6(ICEESS' 18) 67-73

[14] Dagli, Hüseyin and Ergün Tolga (2017), "Türkiye'de Ar-Ge Harcamalarının Firma Karlılı̆ına Etkisi", KTÜ Sosyal Bilimler Enstitüsü Sosyal Bilimler Dergisi, 7/13, June

[15] http://finans.mynet.com/

[16] Eyüboğlu, Sinem and Eyüboğlu, Kemal (2018), “Borsa Istanbul Sektör Endeksleri ile Döviz Kurları Arasındaki ilişkilerin incelenmesi: ARDL Modeli", Ömer Halisdemir 
Üniversitesi Iktisadi ve Idari Bilimler Fakültesi Dergisi Yıl: Ocak, Cilt-Sayı: 11(1) pp: 8-28 